\title{
Meu caminho na crítica
}

\author{
BENEDITO NUNES*
}

Onde Platão acertou, a Filosofia converteu-se em Poesia. Hermann Bloch, A morte de Virgílio.

$\mathrm{N}$ UM DOS ENCONTROS, em Belém, com Clarice Lispector, depois que publiquei O drama da linguagem (São Paulo, Ática, 1989) sobre o conjunto da obra dessa escritora, ela me disse antes do cumprimento de praxe: "Você não é um crítico, mas algo diferente, que não sei o que é". No momento, perturbou-me essa afirmação. Hoje posso ver como foi certeiro, além de encomiástico, o aturdido juízo de Clarice. Ela percebia, lendo o que sobre ela escrevi, que o meu interesse intelectual não nasce nem acaba no campo da crítica literária. Amplificado à compreensão das obras de arte, incluindo as literárias, é também extensivo, em conjunto, à interpretação da cultura e à explicação da Natureza. Um interesse tão reflexivo quanto abrangente, é, portanto, mais filosófico do que apenas literário.

Ora, desde Kant a filosofia também foi chamada de crítica. Não sei por qual das críticas comecei, se foi pela literária ou pela filosófica, tão intimamente se uniram, em minha atividade, desde novinho, e alternativamente, literatura e filosofia.

No "algo diferente" a que Clarice se referia para qualificar-me, estava implícita semelhante união. Não sou um duplo, crítico literário por um lado e filósofo por outro. Constituo um tipo híbrido, mestiço das duas espécies. Literatura e filosofia são hoje, para mim, aquela união convertida em tema reflexivo único, ambas domínios em conflito, embora inseparáveis, intercomunicantes.

Mas nem sempre foi assim. Na idade juvenil escrevi os meus "versinhos" metrificados e rimados e contos ultra-românticos; depois tentei um romance, que não passou do segundo capítulo. Era imitação, talvez, do Menino de Engenho, de José Lins do Rego.

Já estava, portanto, assentado na Literatura antes de passar à Filosofia, aonde cheguei premido pela religião, opressiva àquela época dentro de uma família católica e da qual, coroinha de missas e bênçãos, queria libertar-me. Senão por breve momento acompanhei o entendimento iluminista da religião, como meio de engodo dos mais esclarecidos sobre os mais ignorantes e como meio de controle sujeitando estes àqueles. Entendi, finalmente, o nexo religioso compartilhando da trama tecida pela imaginação, nativa à Literatura e não estranha à Filosofia.

* Depoimento dado durante o III Ciclo de Conferências "Caminhos do Crítico", na Academia Brasileira de Letras, em 17 de maio de 2005. 


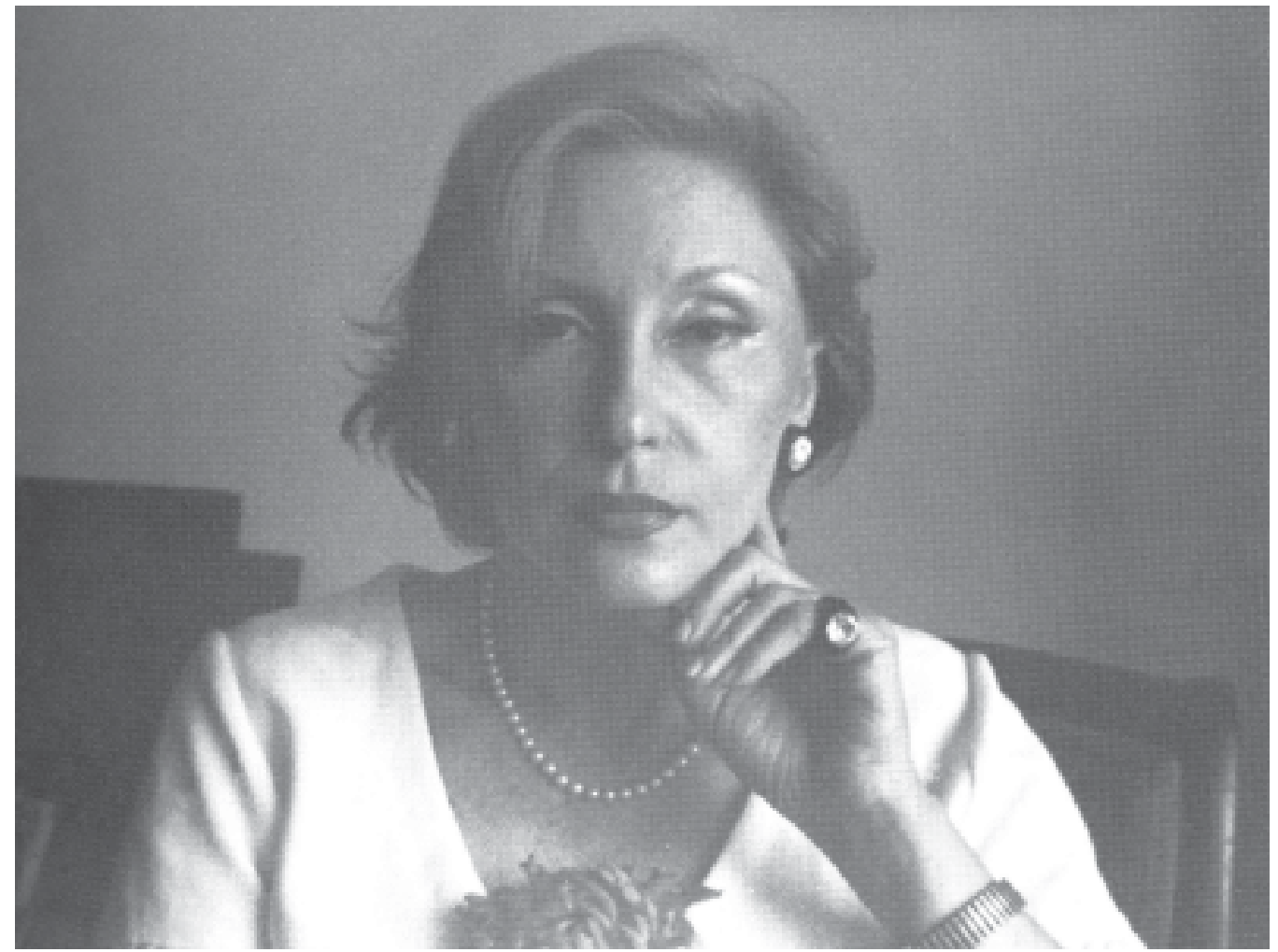

Clarice nasceu em Tchelchenik, na Ucrânia, em 1920 e morreu no Rio de Janeiro, em 1977.

CLAMCE LISPECTOS:

PERTO dO CORAÇÃO SELYAGEM

BOWANCE

Caps de Santa Moss

EDITORA A NOITE - RIO DE JANEIRC

Folha de rosto da $1^{\circ}$ edição da obra.

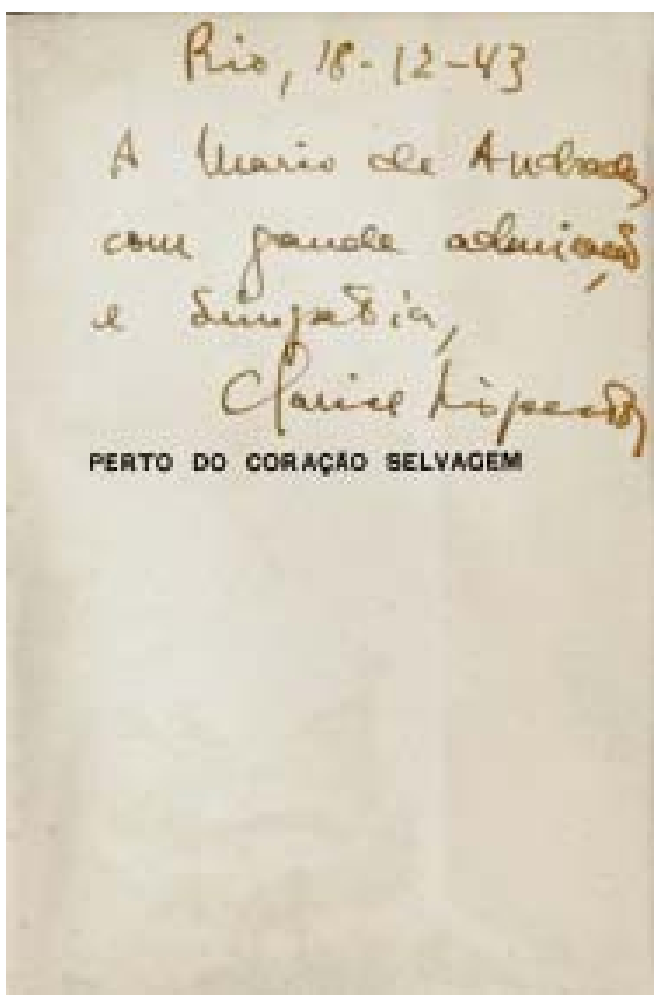

Dedicatória da autora a Mário de Andrade. 
$\mathrm{Na}$ mesma ebulição da primeira juventude, além do mencionado esboço de romance, veio, embalado por prematuro conhecimento de Nietzsche, então lido em espanhol, um surto interrupto de reflexão filosófica, produzindo séries quase semanais de aforismos, numerados em arábico - mais de sessenta ao todo publicados, de 1946 a 1952, sob o título de "Confissões do solitário", no Suplemento Literário, dirigido por Haroldo Maranhão, parte integrante dominical do diário matutino Folha do Norte, em circulação desde o começo do século passado e já extinto, de propriedade do avô dele, o polêmico jornalista Paulo Maranhão, em dissídio com o interventor, e depois governador do Pará, coronel Magalhães Barata, um dos tenentes de 1930.

Esse jornal foi o veículo dessa luta política, e o seu Suplemento o reintrodutor, em época tardia - o final da década de 1940 - no Pará, do movimento modernista, que já tinha sido difundido, entre nós, sem que o soubéssemos (falo pelos meus companheiros de geração como o Haroldo), a partir dos anos de 1920, pela revista Belém Nova.

A minha geração incorporou extemporaneamente esse movimento, restaurando as suas fontes, paulistas principalmente e seus derivados cariocas e mineiros, sem entreter a menor relação com os pioneiros paraenses de Belém Nova, excetuando Bruno de Menezes, para nós tão só o autor da poesia da negritude em Batuque (1931), original contraponto à poesia servonegra de Jorge de Lima. Muitos dentre os pioneiros modernistas do Pará, na década de 1920, como Eneida de Morais, tomaram um Ita no Norte, emigrando para o Rio de Janeiro.

Falecido em 2004, Haroldo Maranhão, meu companheiro de colégio no ginasial, a que me ligou, desde menino, a comum fome de leitura, e também meu confrade literário numa sociedade juvenil que fundamos, com outros então novos - a Academia dos Novos - espelhada na Academia Brasileira de Letras, seguindo os requisitos acadêmicos todos que nos propunha um dos Anuários dessa entidade que ambos avidamente lêramos, deu-nos, na maturidade, três obras-primas romanescas - O tetraneto del rei, extraordinária paródia à prosa quinhentista e sátira à colonização portuguesa no Brasil, Cabelos no coração, biografia imaginária de um dos próceres, no Pará, da Independência de 1822, Felipe Patroni, e o Memorial do fim, amorosa rememoração, de inventiva biográfica, da morte de Machado de Assis. O Suplemento da Folha do Norte, que Haroldo criou e editou, e onde publiquei "As confissões do solitário", foi emblemático para a identidade intelectual da minha geração e particulamente para a sorte do nexo entre literatura e filosofia que, para mim, se formou nessa época, e que só muito mais tarde tornou-se privilegiado objeto de reflexão.

Esse encarte do falecido matutino, $A$ Folha do Norte, agregava, sem distinção, dominicalmente, nas mesmas páginas, dos prosadores e poetas locais aos consagrados modernistas de diferentes naturalidades, mineiros, cariocas e nordestinos, e de distintas gerações - Carlos Drummond, Cecília Meireles, Murilo Mendes, Manuel Bandeira, Ledo Ivo, Marques Rebelo e tantos outros. Assim, 
os escritores estaduais apareciam ao lado dos federais, os das Províncias com os metropolitanos, incluindo os de Belém, que fora prematura, elástica Metrópole, no final do ciclo da Borracha em 1912. Foi o Suplemento da Folha que estampou os fragmentos do confessional solitário: pondo à prova, de encontro a um vago neopaganismo neles preconizado, matrizes de minha formação católica, misturavam conceitos filosóficos e imagens poéticas, sob o foco de uma reflexão cética, certamente agnóstica, sobre problemas religiosos, morais e estéticos, alimentada pela vária, incessante, quase obsessiva leitura de Homero e Shakespeare, Santayana e Unamuno, Pascal e Walt Whitmann, Baudelaire e Goethe, Renan e Gide, Dostoiévski e Kant, Anatole France, Eça de Queiroz e Monteiro Lobato (o de Urupês e o do Pica-pan Amarelo).

As leituras desses filósofos e escritores, a maioria dos quais poetas, alternavam-se num vai e vem constante entre imagem e idéia, entre percepção e conceito. Era um movimento de balouço entre o filosófico e o poético e, portanto, entre idéia e imagem, entre conceito e percepção, que presidiu minha própria formação intelectual. Tendo sido em Filosofia e Literatura autodidata metódico e sistemático, tal movimento entrosou, para mim, sobre um fundo neutro de regulares estudos universitários em Direito concluídos em 1952, quando ainda não existiam, em nosso meio, nem faculdades de Filosofia nem centros de Ciências ou de Letras, as duas sobreditas irmãs adversas. Na maturidade, tal entrosamento constituiria tema preferencial do meu hibridismo crítico.

É aí que reside a pedra de tropeço, a pedra no meio do caminho para o crítico. Se pensado for o hibridismo sem o genuíno balouço entre as duas, parece que estava propondo, de saída, uma subordinação metodológica da literatura à filosofia. A Filosofia seria o caminho real para levar à Literatura. Nada disso. Não pretendi e nem pretendo aplicar a filosofia, como método uniforme, ao conhecimento da literatura, nem fazer da literatura um instrumento de ilustração da filosofia ou uma figuração de verdades filosóficas. Se fosse o caso, teria que recorrer a determinada filosofia - pois que temos filosofia no plural e não no singular - passando então a literatura, sob exame crítico, à condição de serva de um método filosófico. O que nos levaria ao seguinte contrasenso: a Filosofia já está implícita na crítica literária. Sejam quais forem, os métodos da crítica literária sempre têm uma maneira a priori, por assim dizer filosófica, de conceber e de avaliar o alcance do texto literário, em função de um fenômeno mais extensivo que o engloba, seja a linguagem, seja a sociedade, seja a história.

Diante do texto literário, o crítico-leitor passa a examiná-lo sempre de acordo com uma perspectiva avaliadora mais ampla, que a experiência da época ou da sociedade em que vive, já lhe propõe, de antemão na linguagem de todos, como fala comum. Mas dá-se que o próprio autor também se lê. Como crítico-leitor de si mesmo, pode ler-se indagando seu texto diante da instância epocal que lhe prejulga a obra literária ou recapitulando-a diante da concepção filosófica que a ela integrou. O autor pode trabalhar o seu texto do ponto de vista de uma filo- 
sofia - travailler en philosophe - dizia-se no Medievo, tal como Dante trabalhou ao integrar a Escolástica à Divina Comédia - para não falarmos de Lucrécio, que integrou o atomismo de Leucipo, Demócrito e Epicuro ao De Rerum Naturae tal como Goethe incorporaria aos seus dois Fausto o panteísmo de Giordano Bruno, o monismo de Spinoza, as monadas de Leibniz, a idéia estética de Kant e a intuição racional de Fichte. Nessas obras exponenciais do passado, assoma, quando as lemos, uma predisposição filosófica, do mesmo modo que, inversa e complementarmente, filosofias se nos apresentam com acentuado viés literário, a exemplo das filosofias, já em nossa época, de Heidegger, Sartre e Merleau-Ponty.

Afinal, o que, de imediato, há, em comum, entre filosofia e literatura? A linguagem. Como assim? É que ambas só existem em obras de linguagem, o que significa que só existem operativamente ou poeticamente, no sentido originário da palavra grega poiesis.

A Filosofia de Spinoza está configurada nos livros de Spinoza - principalmente naquele denominado Ética. E os livros de Spinoza se estruturam como linguagem escrita, de maneira análoga à Comedia de Dante. Ambas, Comedia danteana e Filosofia de Spinoza são poéticas desse ponto de vista: o da forma escrita que as corporifica, pela qual existem e subsistem no tempo, dirigindo-se a leitores, para veicular-lhes uma mensagem estética, ou seja, uma maneira de sentir por imagens, se a obra é literária, mormente se for poesia, ou para veicularlhes uma maneira de pensar, munida de recursos retóricos para persuadi-los, se a obra é filosófica. Mas concretizando-se em obras cada um desses domínios, a linguagem, o discurso escrito que têm em comum é, para dizê-lo de maneira simples - com o risco de simplificação - trabalhado de modo diferente: na filosofia preponderam a proposição e o argumento, em que prima o conceito ou o significado, na literatura preponderam a imagem e o significante, bem como os chamados tropos (metáfora, metonímia etc). Uma e outra, porém, como obras de linguagem posta em ação - fontes da palavra ativa, atuante - permitem-nos discernir o real para além do dado imediato, empírico.

No entanto, é preciso dizê-lo, em proveito da identificação de meu caminho crítico, essas duas linguagens na maioria das vezes se traspassam em seus próprios componentes extremos, como obras repassadas pela mesma vis poética, formativa: entra o poético na filosofia e entra o filosófico na poesia, esta palavra aqui já usada como o essencial da literatura, ou, aproveitando-se a expressão de Valéry, a literatura reduzida a seu princípio ativo. Se, portanto, há traspasse, é porque, nesse nível, filosofia e poesia se encontram, se correspondem, se atravessam, e mesmo assim continuam diferentes. Sem coincidirem, enriquecem-se mutuamente.

Mas esse encontro de que estamos falando, já não teria ocorrido desde o século XVIII, sob a mediação da disciplina filosófica denominada Estética, então surgente na órbita do pensamento kantiano, em seu terceiro desdobramento, como crítica do juízo relativo ao Belo natural, ao Belo artístico e à finalidade? Se 
hoje, porém, estudamos o desenvolvimento da Estética entre nós, constatamos que essa disciplina só se configurou de maneira autônoma, no Brasil, em tempos recentes. Sua existência, nova e esporádica, é secundada, senão suprida, pela crítica literária e artística, exercendo, em suplência, a função de discernimento estético. Não obstante, os românticos, principalmente os alemães, contemporâneos do surgimento da Estética no idealismo posterior a Kant, e entre eles um Friedrich Schlegel e um Novalis, defenderam a supremacia da Crítica, com efeitos estéticos. Defenderam, ainda, em nome das duas, a coincidência da Filosofia com a Poesia como equivalência entre gêneros. Assim, a filosofia é uma espécie de poesia e a poesia uma espécie de filosofia. Na verdade, os românticos sobrepunham as duas fraternas adversárias, porque adotavam o ponto de vista fichtiano, ou seja, do discípulo de Kant, segundo o qual, defendiam, contra o Mestre, a existência de uma intuição intelectual, capaz de criar o objeto no momento de conhecê-lo. A Filosofia passava a ser arte e poesia; e arte e poesia eram equivalentes à Filosofia.

Porém o traspasse de uma na outra é, antes de tudo, transação historicamente efetivada, que mantém a identidade de cada parceira, no traspasse mútuo de ambas, em seguimento a um trânsito de mão dupla de filósofos e poetas - os primeiros transando com os segundos e vice-versa. Simetricamente, um poeta, Antonio Machado, sob a responsabilidade de seu heterônimo, Juan de Mairena, com a personalidade fictícia de professor de Retórica, e um filósofo, Heidegger, inclinado à poesia, figuraram essa transa ou transação, pelo último batizada de diálogo, entre as participantes de conflito quase trimilenar, se contarmos da época de Platão ou do grande escrito, A República, do fundador da Academia, o primeiro marco da contenda opondo o partido do pensamento filosófico à facção dos que poetam.

Juan de Mairena escreve: "Hay hombres, decia mi maestro, que van de la Poetica a la Filosofia; outros que van de la Filosofia a la Poética. Lo inevitable es ir de lo uno a lo outro, en esto como en todo" (Há homens, dizia meu mestre, que vão da Poética à Filosofia. O inevitável, nisso como em tudo, é ir de um termo a outro).

A primeira parte do percurso de ida e vinda aí exposto, poderia descrever o movimento intelectual de certos poetas, como o próprio Antonio Machado, Fernando Pessoa, Carlos Drummond de Andrade, João Cabral de Melo Neto, Rilke, Paul Valéry, Eliot, na direção da Filosofia; a segunda parte do percurso descreveria a órbita de filósofos como Sartre, Merleau-Ponty, Heidegger, Hannah Arendt, Gaston Bachelard, Michel Foucault, Ludwig Wittgenstein e Paul Ricoeur na direção da poesia, tal como anteriormente concebida. Num confronto desse tipo, há, de início, duas conseqüências importantes: apesar do traspasse ou da mútua conversão dos termos, poeta e filósofo conservam cada qual a sua identidade própria; e, ainda, o traspasse deixa patente que filosofia e poesia, longe de serem unidades fixas, monádicas, sem janelas, mantendo entre si conexão unívoca 
e herárquica, à maneira de duas disciplinas distintas, conforme nos legou a tradição clássica que Hegel averbou ao absorver a poesia na filosofia, são unidades móveis, em conexão recíproca.

Mas há uma terceira conseqüência a ressaltar. É o fato de que nessa conexão recíproca, a filosofia faz da obra literária como tal objeto de sua indagação (o que ela é, ao que visa, qual a sua estrutura) e a obra, por sua vez, reverte sobre a Filosofia, da qual, ela, obra, se faz, como poética, a instância concreta, reveladora (ou desveladora) das originariamente abstratas indagações filosóficas. Eis, em resumo, o procedimento geral que tenho seguido. Daí a quarta conseqüência: não é a Filosofia que impõe seu método à parceira, mas é esta mesma que o sugere; a Filosofia pode garantir ou legitimar a escolha de um ou mais de um método, eis que para o conhecimento da Literatura, a conveniência deste e daquele é assentada filosoficamente em estado de simpósio: cada qual pode servir ao iluminar de certa maneira a obra estudada. Reciprocamente a obra estudada também pode oferecer um ponto incisivo de aclaramento filosófico.

Foi sob tal foco dúplice que comecei a examinar, entre outras, obras como o singular romance Grande sertão: veredas, de Guimarães Rosa, síntese das chamadas formas simples, estudadas por André Jolles - entre elas o enigma e o mito - e como A paixão segundo G.H., de Clarice Lispector, narrativa de personagem inominada, no círculo de insólita transfiguração do real, semelhante às passadas de uma experiência mística que a fiç̧ão parodiasse.

Nesse romance de Guimarães Rosa, a poesia cede lugar à sua nobre ancestral, o mito, contra a qual luta, desde o início, desde a aurora grega a insurgente força intelectual da Filosofia. E esse mito, nada mais nada menos do que o pacto com o Demônio, presumivelmente firmado pelo personagem narrador, o jagunço Riobaldo, modula o tom épico da narrativa até ser, por sua vez, deslocado, graças ao ânimo dubitativo do mesmo narrador, discutindo consigo mesmo se o Diabo mesmo existe, à condição de potência obscura do ânimo desse turbulento herói, concentrada no seu inconfesso amor por um companheiro de cangaço, Diadorim. A solução do romance está no Sertão-Mundo. Meio dos opostos extremos, Deus e o Diabo, o Sertão-Mundo é o terceiro termo, que os religa como aspectos complementares de uma mesma realidade problemática. Suspenso à indagação reflexiva que o neutralizou, o Mito nos entrega finalmente a um ethos, quer dizer, à inquietação ética ou a uma ética da inquietação, que converte a obra literária numa instância de questionamento filosófico. Nesse extremo limite da experiência do narrador e da matéria fingidamente oral de seu contar romanesco, é que a Filosofia é chamada "a nos servir de guia", como disse Walter Benjamin a propósito das Afinidades eletivas, de Goethe. E ela vai retomar a referida obra de Guimarães Rosa na questão do tempo que a impregna, quer no modo de narrar (recordação do acontecido), quer no teor agonístico da matéria narrada (combates e embates internos do bando). Em suma, a combinação, no romance, do ethos e do mito, produz uma apresentação poética da existência 
humana temporalizada como travessia. "O Diabo não há! é o que digo, se for... Existe é homem humano. Travessia”.

Em $A$ paixão segundo G.H. não é a Filosofia que serve de guia. A trajetória mística seguida pela personagem é uma contra-filosofia que, em vez do discurso de aclaramento do real, lhe impõe, pelo uso mesmo da linguagem levada a seu extremo limite de expressão, a visão extática, o descortínio silencioso das coisas.

Eu tenho à medida que designo - e este é o esplendor de se ter uma linguagem.

Mas eu tenho muito mais à medida que não consigo designar. A realidade é a matéria-prima, a linguagem é o modo como vou buscá-la - e como não acho. Mas é do buscar e não achar que nasce o que eu não conhecia, e que instantaneamente reconheço. A linguagem é o meu esforço humano. Por destino tenho que ir buscar e por destino volto com as mãos vazias. Mas volto com o indizível.

Aqui o arrebatamento da visão extática sobrepõe o mostrar ao dizer, o silêncio do olhar à sonoridade das palavras, o vislumbre intuitivo à frase. O poético, que se confunde com o místico, tal como Wittgenstein o entendia, é o aparecer do que se mostra, o indizível. "Das Mystisch zeigt sich" (O místico se mostra).

É difícil encontrar um poeta que, como Fernando Pessoa, tenha, sob suas diversas máscaras ou heterônimos, tão freqüentemente brincado com o místico e também com o mito. E nenhum outro como ele, dentro da língua portuguesa, procurou ligar-se, de maneira lúdica, à Filosofia e de modo particular à Metafísica. É o mito, esse "nada que é tudo", a que ele visa em "Mensagem" - o mito do fundador da pátria ou da língua portuguesa. E o faz no seu modo peculiar de depuração da experiência individual, semelhante a um processo de ascese mística, por ele denominado de fingimento. É o que nos diz Fernando Pessoa em "Psicografia" e em outros poemas seus: "O poeta é um fingidor/ Finge tão completamente/ que chega a fingir que é dor/ a dor que deveras sente...".

Fingir é um estratagema para se alcançar a fugidia verdade dos sentimentos. Como saber o que verdadeiramente sinto, quando vivo em permanente relação com os outros e eu mesmo me desdobro, parecendo um outro para mim mesmo? Se, como Fernando Pessoa diz, em certa nota sibilina de Álvaro de Campos, fingir é conhecer-se, então o conhecimento é ilusório e fictício. Nossas verdades, também afirmava ele, num diapasão nietzscheano, são mentiras vitais. E assim podemos inventar-nos e dar à luz, em nome de tantos que podemos ser, afivelando as máscaras de nossos papéis sociais, mundos imaginados e possíveis.

Fernando Pessoa subscreveu os imaginários universos de seus heterônimos, "um drama em gente" desse poeta que já se outrava ao tentar ser si mesmo - o bucólico Alberto Caeiro, o greco-decadente do estóico Ricardo Reis a invocar sua Lídia, como Ovídio invocou Leuconae numa ode, de encontro ao insondável destino de cada um, o existencial, da náusea e da angústia, de Álvaro de Campos, sitiado entre as interrogações maiores do nascimento e da morte. Subscreveu-os à medida que se escrevia diferente; pensava-se ortônimo, e era o 
heterônimo em prosa do Livro do desassossego, Bernardo Soares. Conhecer-se é figurar possíveis modos de existir, "novos tipos de fingir que compreendo o mundo, ou antes de fingir que se pode compreendê-lo". E a cada tipo de compreensão corresponde uma ciência não real, mas virtual, chamada Filosofia, que se extrema nas concepções metafísicas do Universo, por nós criadas como se fossem obras de arte. Podemos forjar metafísicas engraçadas, mas "sem lhes ligar intenção alguma de verdade, exatamente como em arte se descreve e expõe uma emoção interessante, sem se considerar que corresponde ou não a uma verdade objetiva de qualquer espécie". Então a Filosofia não passa de uma certa espécie de poesia, justificando-se assim o paradoxo formulado, em forma de trocadilho, por Pessoa acerca de sua identidade própria: "Eu era um poeta impulsionado pela Filosofia e não um filósofo com faculdades poéticas".

Ainda dentro de nossa língua, um poeta reflexivo como Carlos Drummond de Andrade, alto beneficiário da "musa filosófica”, na expressão de José Guilherme Merquior, levou a cabo, em poemas elegíacos, como "Passagem da Noite" e "Anoitecer", estirada meditação sobre a morte, em dramático confronto a essa possibilidade extrema da existência. Mas mesmo assim, conforme nos mostram os tercetos de "Cantilena Prévia", em A falta que ama (Boitempo I), o senso trágico desse confronto não é excludente do senso de humor, provindo do efeito jocoso dos refrões, tão só pela sonoridade isolada, em choque ou em ressonância com o sentido: "Don don dorondondon / É o castelo de Drummond / que vai à penhora // Don don dorondondon / É a soberba de Drummond que vai-se embora. / Don don dorondondon / É o prazo de Drummond / que termina agora. / É o prazo de Drummond que ainda não termina. / Din din resta uma resina./"

É uma cantiga da morte antecipada. O primeiro refrão - onomatopéia do sino de pregão da penhora? - é também rima em eco do nome do poeta. Há uma imitação do desafio folclórico; a penhora do Castelo é indefinidamente protelada: "Din din Resta uma farinha / de substantivo, infra-som / de voz, na voz de Drummond? /" Quem está para morrer, o morituro, aceita a anulação da consciência em abono de maior ciência adquirida. Esse paradoxo da anulação da consciência é acentuado pelo último refrão, popularesco (rinfonfon), sugerindo um significado que não há: "Dindon drondin din / O que sabe agora / Não o diz Drummond // Sabe para si / Sabe por si só. / Sabe só, sem som //É de rinfonfon. / É sem cor nem tom / É completo / É bom. //"

A proeza do humor da "musa filosófica" do poeta é a associação, nesses versos, do pathos trágico da desindividuação dionisíaca com o entendimento sarcástico da finitude humana.

Nunca são diretas e sim transversais as relações entre Poesia e Filosofia. Se o poeta é eminentemente crítico como João Cabral de Melo Neto, mais prosperam, com pontos de incidência característicos sobre a linguagem, essas relações transversais. 


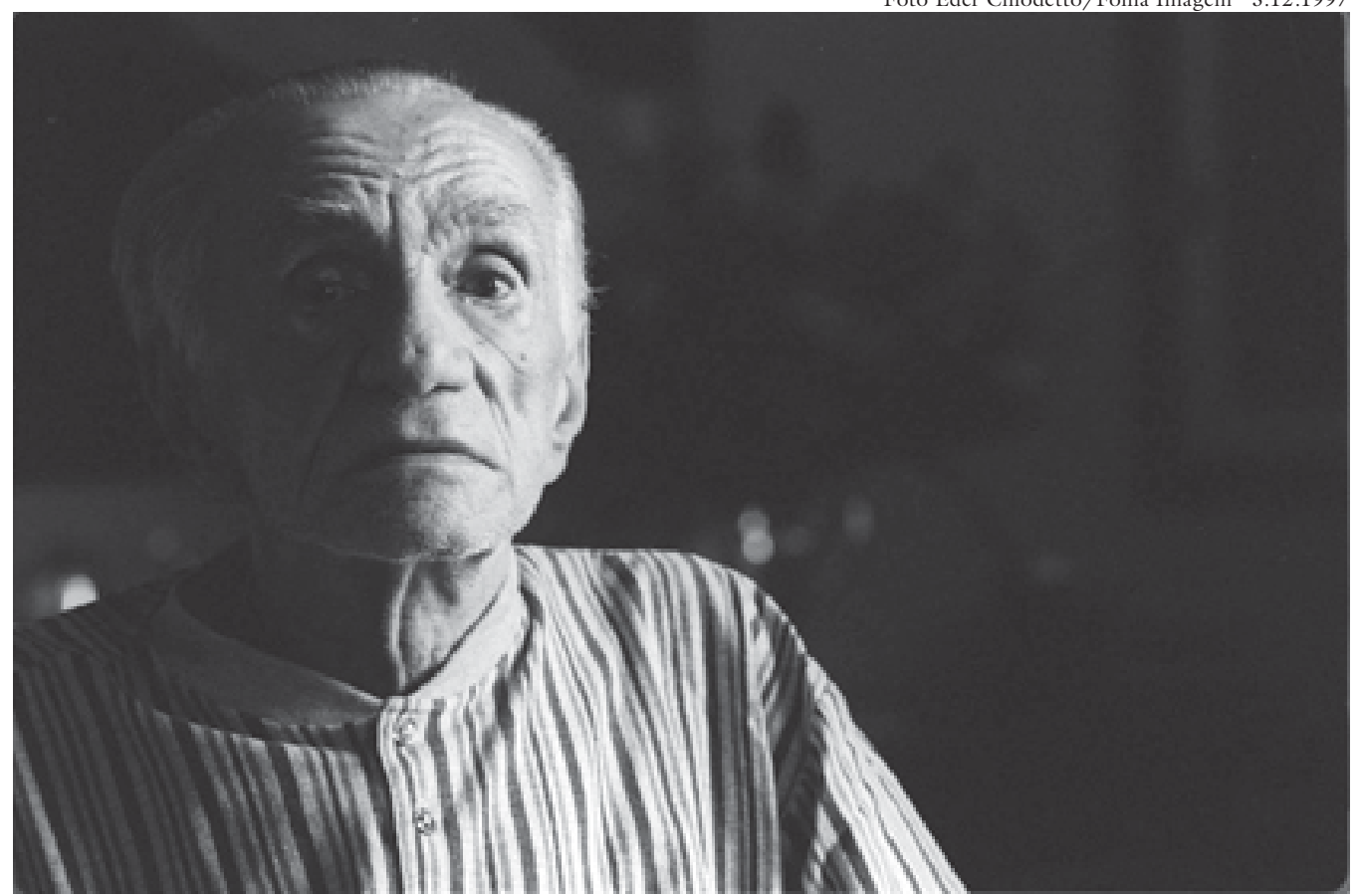

O escritor João Cabral de Melo Neto no seu apartamento na zona sul do Rio de Janeiro (RJ).

O primeiro ponto é a poesia nascendo, em contraposição ao estado de êxtase, à inspiração, de um movimento de ascese, de depuração psicológica e literária, que cria o poema como "trabalho de arte". O segundo diz respeito ao uso predominante, desde Pedra do Sono, dos nomes - preferentemente substantivos concretos - designativos de coisas naturais ou fabricadas, de lugares, paisagens, espécies de categorias de pessoas ou atividades, que acabam se tornando, a partir de Duas águas, como objetos temáticos, peças fundamentais de um repertório léxico, em geral entitulando as composições - "O vento no canavial", "O ovo de galinha", "Paisagem com cupins" etc.

O segundo ponto, que acompanha a oscilação do concreto ao abstrato e do abstrato ao concreto na obra de João Cabral, é a transposição de qualidades das coisas humanas às naturais, e, vice-versa, das naturais às humanas, por um desdobramento dos vocábulos-imagens nas enunciações dos versos descritivos. Em "O vento no canavial", o canavial se apresenta sucessivamente, "como um mar sem navios, / papel em branco de escrita", “[...] um grande lençol / sem dobras e sem bainha $[\ldots]$ "

O terceiro ponto direciona a linguagem para aquela parte do real perceptível que pertence ao mundo interior, mas como experiência corporal, afetiva, englobando a vida dos sentimentos numa esquiva à introspecção. Assim, em "A mulher e a casa", a sedução do corpo feminino investe-se no corpo de uma casa ("Tua sedução é menos / de mulher do que de casa: / pois vem de como é por dentro / ou por detrás da fachada"). Dessa forma torna-se patente a inclinação didática da poesia cabralina, congregando lições de inconformismo numa peda- 
gogia da palavra ou numa educação pela pedra: “[...] por lições; / para aprender da pedra, freqüentá-la”. Essa lição restaura a transitividade da poesia e seu influxo humanístico.

Sempre a mesma e sempre diferente, a poesia de João Cabral é uma poesia agônica. Repete em cada um de seus momentos a experiência de um perpétuo recomeço.

O mais notável recomeço que experimentou a poesia de João Cabral em sua última fase foi o surto memorialístico em "Escola das Facas", "Agrestes" e "Crime na Calle Relator" (1987), principalmente, com o que revertido fica o seu dominante regime de suspensão subjetivista. Descobriria o poeta crítico, finalmente, que o seu fazer "poesia com coisas" é um modo desviado, negativo, de dizer-se: "Não haverá nesse pudor / de falar-me uma confissão, / uma indireta confissão, pelo avesso, e sempre impudor?”.

Fora de nossa língua, dois poetas, o alemão Rainer Maria Rilke, conhecido como autor das "Elegias de Duino" e dos "Sonetos a Orfeu", e o inglês T. S. (Thomas Stern) Eliot, que nos deu principalmente "Terra devastada" ("Waste Land") e "Quatro quartetos" ("Four Quartets"), comprovam o nexo transversal da Filosofia com a Poesia. Nos dois poetas, a Filosofia se aproxima da Mística e a linguagem poética vinga como gnose intuitiva do real.

Rilke começa interpelando Deus em O livro das horas (1899), como ser dependente do homem, segundo o concebera o místico medieval Meister Eckhardt, e aprofunda numa espécie de romance autobiográfico, os Cadernos de Malte Laurids Brigge, a morte como experiência vivida e amadurecida em cada homem. Esses temas se articulariam sob a égide do Anjo, mensageiro transmissor do divino e tardio musageta, tanto nas elegias quanto nos sonetos, embora de maneiras diferentes, sob o pressuposto da carga existencial do verso. Por meio do verso, poesia e vida se entrosam levando poeta e leitor a um estado contemplativo. No poema bem acabado se manifestaria o mesmo esplendor que nos dispensa o Torso arcaico de Apolo ou a Vitória de Samotrácia. Desses blocos surde um poder conversor, um apelo imemorial que nos atinge: “[...] pois aí não há ponto / que não te veja. Forçoso é mudares de vida".

As elegias que o Anjo freqüenta são noturnos, no sentido elegíaco da composição musical. Distingue-as a tonalidade do desconhecido, do estranho, do inóspito, que se coaduna com o conhecimento da morte - experiência da perda da habitação humana, dos desejos, do amor. Essa experiência é antecipada pela dissipação de nosso estar aqui (Hierserin), do nosso ser no mundo. E, no entanto, "Estar aqui é magnífico. Vós o soubestes, jovens mulheres, também vós...". Nas dez elegias, cada qual definida por um tema - o amor, a morte, o herói, a amante, os saltimbancos e os animais - sobrelevam imagens, como mundo, espaço, destino e aberto, que prepararam conceitos fundamentais das filosofias da existência. Dentre eles, o aberto, correspondente ao termo conceptual Erschlossenheit (abrimento, fresta, passagem) em Ser e tempo de Heidegger. 
Dois conjuntos de poemas - "Waste Land" e "Four Quartets"- demarcam a transversalidade do nexo da filosofia com a literatura em seu principio poético na obra de T. S. Eliot. O primeiro conjunto, na verdade composto de fragmentos, como que responde à laceração moral e espiritual do mundo moderno. Já os "Quatro quartetos" são "grandes poemas filosófico-religiosos" que fazem passar ao primeiro plano, numa tentativa de síntese, as heranças mítica e mística do Oriente e do Ocidente. Eles reúnem desde o ensinamento de Heráclito à visão mística de santos, como São João da Cruz, de filósofos como Platão e Santo Agostinho, e dos livros sapienciais do Oriente, como o Tao te king e o BhagavadGita. Assim, vê-se que entra em linha de conta a experiência de culturas e de gerações. Razão há, portanto, para que o autor invoque mais do que a memória individual, apelando tanto para os vivos quanto para os mortos. Nosso nascimento é uma espécie de morte. Morremos com os que agonizam e nascemos com os que morrem. A poesia constitui a cadeia dessa experiência letal. E é, ao mesmo tempo, a poesia que libera o homem da morte graças à função da memória, correlata ao circuito da História interligando passado, presente e futuro a uma parcela de eternidade conquistada em cada época.

Jean-Paul Sartre tem prioridade do lado dos filósofos, nessa exposição, por que foi nele que se extremou a relação entre Filosofia e Literatura, aqui estudada, num nexo trilateral da mesma atividade de escritor, ora romancista e dramaturgo, ora ensaísta em A imaginação e o imaginário, e tratadista em Ser e nada. Essa trilateralidade é marcada por cruzamentos internos - da Filosofia com o drama e com o romance, do dramático e do romanesco com a concepção filosófica. A concepção filosófica de Sartre esboçada na novela "A náusea" ("La nausée"), e que resumida foi em L'existentialisme est un humanisme (ele criou o termo existencialismo), espraiou-se em L'être et le néant, integrando conceitos provindos de Hegel e de Heidegger numa metodologia fenomenológica oriunda de uma interpretação de Husserl, o fundador da Fenomenologia e mestre de Heidegger. Filosóficos na intenção, os dramas de Sartre, decisivo exemplo de cruzamento interno, exteriorizam a estrutura eminentemente dramática da existência humana descrita filosoficamente por esse escritor e pensador francês.

Requalificando a Fenomenologia como hermenêutica do sentido do ser na existência humana situada no mundo e estruturada pelo tempo, em sua obraprima interrompida Sein und Zeit (1927), e depois como interpretação dos présocráticos e dos poetas alemães (Holderlin, Trakl, Rilke), Heidegger, com quem mais afinidades tenho, tentou, numa segunda fase, libertar-se de elementos subjetivistas e antropológicos, de que estaria eivado aquele livro, e que atribui ao curso invasor da Metafísica moderna a partir de Descartes, para soltar a linguagem desses pensadores e poetas a fim de que viessem a falar por si mesmos. Mas nesse extremo limite de sua Filosofia, Heidegger, sobre quem escrevi longo texto, "Passagem para o potético", opta por uma espécie de reviravolta do pensamento numa prática meditante, que vai de encontro à tecnificação do mundo, 
para isso aderindo ao canto, ao "fervor pensante da recordação" do ser a que nos chama a poesia. "Cantar e pensar são os dois troncos vizinhos do ato poético", afirma o mestre alemão em seu estilo aforismático da segunda e última fase.

Não esqueçamos porém que o idioma filosófico de Heidegger é também poético na escrita mesma de Ser e tempo, que abunda na criação de palavras, substantivos (Sein-zum- Tode) e verbos (welten, zeitigen). Destaca-se nele, sobretudo, o termo basilar daquele tratado, Dasein. Na língua alemã com o significado comum, dicionarizado, de existir, esse termo, no vocabulário heideggeriano, representa tanto o homem como o aí do ser, o ente no qual o ser se manifesta, quanto o ser aí, existente no mundo, de tal forma que sua estrutura lhe impõe um movimento extático, fora de si - a temporalidade, condição sine qua do tempo astronômico, dos calendários e dos relógios. Daí afirmar Heidegger que, como Dasein, o homem é temporal no fundo de seu ser. A temporalidade o ajuda a contornar a barreira da Metafísica, que impõe o ser como ente, e a transitar para o desvelamento do ser na linguagem dos poetas. Na passagem para o poético, a filosofia alcança o seu fim (Ende): ensinar o homem a habitar poeticamente a Terra.

O habitar é menos e mais que o conhecer. É menos porque não se coaduna à mera representação das coisas no espaço e no tempo. Eé mais porque pressupõe a prévia posse (Vorhabe) do ser que nos engloba. Focalizando essa posse como experiência primária, a filosofia atravessa o Rubicão da linguagem para reencontrar o silêncio que nos cerca. Do mesmo modo, a Filosofia descola do visível que a percepção capta para o invisível já apreendido naquele. Eis aí uma versão arquiresumida do pensamento de Maurice Merleau-Ponty, que começou por uma Phénomenologie de la perception e cujo último livro foi o inacabado e póstumo Le visible et l'invisible.

Propondo uma Metafísica sem Absoluto, a visar como realidade nativa o ser-no-mundo, Merleau-Ponty, a quem Hannah Arendt aderiu, reconhece, no entanto, a dimensão ontológica da Arte e da palavra poética, apontando, em confirmação, a pintura de Cézanne e La recherche du temps perdu de Marcel Proust. Cézanne não apenas nos ensina a ver. Ensina-nos o que é a visão e que a coisa natural nada mais é do que uma unidade simbólica, formado pela religação das qualidades sensíveis na cor e na forma. A montanha Saint-Victoire é uma fisionomia do visível, como fisionomia do visível é as Lavandières de Renoir. A água que figura nesse quadro não é a água do Mediterrâneo, mas o "emblema de uma maneira de habitar o mundo, de tratá-lo, de interpretar pelo rosto como pelo vestuário, pela agilidade do gesto ou pela inércia do corpo - enfim o emblema de uma certa relação com o ser" (Signes, p. 68). Ambos, Cézanne e Renoir, desvendam-nos o segredo da visão.

Com a Literatura, sob a clave do poético, a Filosofia aprende o segredo da escrita: a enunciação nos dá mais do que a proposição e o argumento. Essa descoincidência entre enunciação e proposição encadeia o paradoxal movimento 
da escrita literária: o verdadeiro despontando do imaginário, da expressividade da palavra, como a ficção de Marcel Proust sintetizou.

Mas seja como texto literário, seja como pintura, o poder conversor da arte estreita a afinidade entre o artista e o filósofo, posto que ambos, conforme o enfoque de "Le metaphysique de l'homme" (Sens et non-sens), estão a braços com a descrição da inexaurível experiência humana - de sua raiz perceptiva à sua floração na linguagem, do plano corporal ao intencional, das vivências pessoais aos vínculos interpessoais ou aos laços da memória coletiva. Saber ver e saber dizer são também imperativos da escrita, do discurso filosófico. Desse ponto de vista, a Filosofia é criação no sentido radical, o que aprofunda "consideravelmente a estimativa de Souriau sobre a Filosofia como arte suprema" (Le visible et l'invisible, p. 251). Conseqüentemente, a descrição filosófica seria convergente ao dizer poético.

Mas para entender essa convergência, não basta assinalarmos, com Habermas, “a guinada linguística” em nossa cultura. É preciso, na verdade, considerar que as mudanças do pensamento, nesta época, como o declínio da Metafísica e a "morte de Deus", já tinham aproximado Filosofia e Literatura.

Em sua linguagem mista, sublime e vulgar, alta e baixa, a poesia moderna, com traços de religiosidade e anti-religiosidade, à busca, antes de qualquer outra das artes, de uma unio mistica secularizada, interiorizou, desde os poemas de Baudelaire, a "morte de Deus", depois do abalo produzido pela Crítica da razão pura, início da crise, na Metafísica, da noção de substância (os paralogismos), e, conseqüentemente, da alma, da unidade do sujeito e de sua imortalidade.

No terreno filosófico, essa crise, culminando quando, desligado o alto do baixo, o sensível do supra-sensível, deu-se a descoberta da vida (biologicamente considerada), o que permitiu que se divisasse a importância ontológica da parte baixa, subterrânea, pré-teórica, da experiência, em que a teoria se funda e acima da qual se eleva. Em conseqüência do que tematizada ficou essa parte irreflexiva, distinta do sujeito humano como consciência reflexiva: a facticidade e a compreensão do existente como ser-aí (Dasein), o que nos daria o grande bloco hermenêutico do pensamento contemporâneo, construído por Heidegger e enriquecido por Hans George Gadamer e Paul Ricoeur. Compreendendo o mundo e a si mesmo como poder-ser, o Dasein não conhece teoricamente nem a Natureza nem a si mesmo antes de interpretar-se; o conhecimento funda-se no ser interpretado como "tal ou qual", isto é, previamente compreendido na fala, no discurso que nos constitui como ente, e que possibilita os enunciados proposicionais. Mas a verdade pré-teórica, originária, não reside nesses enunciados e sim no desvelamento da compreensão, que é temporal e histórica.

Verifica-se, dessa forma, notável transposição: desloca-se o eixo proposicional da noção de verdade para o âmbito do discurso, da linguagem ou da fala, como o solo comum de nossa experiência, enfeixando as possibilidades do conhecimento científico, da poesia e da filosofia. E é precisamente aí onde poesia e 
filosofia já se avizinham. Tal vizinhança sustenta a aproximação histórica de poetas e filósofos no atual panorama da cultura.

Fáctico nos sentimentos fundamentais da angústia, da alegria, do medo e do tédio, compreendendo-se no imediato de sua situação e nas possibilidades que o tornam temporal e, portanto, ente do longínquo jamais coincidente consigo mesmo, o homem é, como ser-aí ou Dasein, pela compreensão que o projeta no mundo, ser de imaginação e não apenas de razão. Não será preciso fazer, como Coleridge, a apologia da imaginação. Salto no conceito e acima dele, a imaginação é comum de dois, à Poesia e à Filosofia.

Sob esse foco, o mesmo da linguagem-discurso ou da fala, anteriormente referido, também se poderá distinguir, além dos componentes poéticos (metáforas, metonímias, paronomasia etc.), os contrafortes retóricos dos escritos filosóficos - que são os seus mecanismos de persuasão, tais como os circunlóquios de Descartes (estratégias, dir-se-á hoje), a ordem geométrica de Spinoza, as retificações kantianas (como nas Introduções à Crítica do juizo), o pensamento "romanceado" de Hegel, principalmente na Fenomenologia do espirito (o herói é o mesmo Geist, conforme observaria Santayana), a belle écriture bergsoniana, o estilo journal intime de Kierkegaard (compare-se com Amiel), os trocadilhos e paronomásias heideggerianas, os gêneros (o tratado, o ensaio, o diálogo, este freqüente no Renascimento e nos séculos XVII e XVIII, em recesso no século XIX, e raro e ralo hoje), sua individualização num estilo, sua conformação verbal no todo de uma obra de linguagem.

A missão de "dialogar" com a Poesia - que pensaria cantando, em ritmo deferida por Heidegger à Filosofia, de pois de Ser e tempo (Sein und Zeit) é, para os filósofos, de um modo geral, um diálogo limite, na fímbria da própria Filosofia e já para fora da Lógica. Mas para os poetas, esse diálogo com a Filosofia é um diálogo de limiar, que se incorpora ao trabalho de elaboração do poema - Camões e os barrocos absorvendo os neoplatônicos, Rimbaud, os gnósticos, Fernando Pessoa, Nietzsche, e tantos outros pensadores que ressurgem filtrados na criação, depois de incorporados à experiência pessoal, histórica e cultural do poeta, ou seja,'à sua interpretação compreensiva de si mesma como ser no mundo.

Assim, o movimento de vai e vem da Filosofia à Poesia e da Poesia à Filosofia, de que Antonio Machado/Mairena falou, remonta à compreensão preliminar, linguageira, do ser no meio do qual nos encontramos. "Na medida em que a Filosofia se torna mais consciente da maneira pela qual o pensamento requer a linguagem, mais ela se aproxima da poesia..." (Waren Shibbles, Wittgenstein, Linguagem e filosofia). O pensamento requer a linguagem interligada à fala, ao discurso. E requerendo a linguagem, o pensamento já se interpretou nela. Por isso, a Poesia moderna, consciente de sua fatura verbal, como nô-lo mostra a ocorrência nesta da tematização predominante do ato poético, é a que mais se aproxima da Filosofia. Tal é o requerimento da linguagem sobre nossa experiência de interpretantes, que se poderia dizer, que, para nós, leitores, a literatura 
pensa, não apenas no sentido da bem lograda tentativa de Macherey, de extrair a Filosofia implícita de certas obras literárias, como romances franceses dos séculos XVIII e XIX, mas, também, no sentido do efeito anagógico, conversor, propiciado pelo ato de sua leitura. O efeito anagógico é semelhante à súbita "iluminação" dos místicos, sejam eles orientais ou ocidentais. $\mathrm{Na}$ expressão do poeta jesuíta Gerard Manley Hopkins, trata-se de um inscape, levando-nos para além de nós mesmos, do entendimento banal do cotidiano e para fora da couraça das ideologias.

No entanto, jamais podemos esquecer o que Nietzsche e Fernando Pessoa afirmaram: os poetas mentem e fingem muitas vezes, e muitas vezes, como já sabiam as Musas, que inspiraram a Hesíodo sua teogonia, falam a verdade. Mas de que verdade essencial podem falar as obras de literatura, particularmente as poéticas, tanto no sentido estrito quanto no amplo para o filósofo?

Além das respostas de Heidegger e Sartre, já examinadas, merecem consideração a de Paul Ricoeur, por via semântico-hermenêutica e a do neopositivista heterodoxo, marginal, Ludwig Wittgenstein, obtida pelo seu método de excludência lógica.

O lado semântico da resposta de Ricoeur concerne ao plano da escrita, a que pertence o discurso como obra. A escrita abstrai a relação dos interlocutores no discurso falado, suspendendo, portanto, os referenciais correntes dos enunciados descritivos, afetos à verdade proposicional. E assim o texto literário, poético, devolve ao leitor, com um novo referencial, o mundo de sua experiência préteórica - o mundo do texto. O mundo do texto pode tornar-se texto do mundo porque desprendido fica das intenções pessoais do autor. É por esse lado hermenêutico que a obra de discurso (seja poesia seja prosa), é capaz de dar-nos variações imaginativas sobre o real, ou, como poderia dizer-nos Northrop Frye, enunciados hipotéticos da ação humana, reveladoras do ethos. Sem literatura de ficção jamais teríamos conhecimento dos conflitos éticos e do empenho moral do homem.

Concordando com um dos fundadores da Lógica simbólica, Gottlob Frege (1848-1925) acerca do valor de verdade da referência, Ludwig Wittgenstein negou o conhecimento ético, mas não a importância do empenho moral do homem. Para ele, paradoxalmente, o seu Tratactus logico-philosophicus (1922) era uma introdução à Ética. Introdução negativa, por certo: os enunciados sobre o bem ou a felicidade, que tendem a absolutizar-se, são insustentáveis e sem sentido. Não é possível escrever uma Ética - disse-o Wittgenstein numa conferência. Por quê?

Porque os juízos da Ética, que não correspondem a estados de fato, seriam intraduzíveis, inexpressáveis. Faltariam proposições que os asseverassem. "Sobre o que não podemos dizer, é melhor silenciar", escreveu Wittgenstein. O ético, o religioso e o metafísico pertencem à categoria do indizível, isto é, daquilo que não pode ser articulado proposicionalmente. O indizível é o místico. "Das Mystische zeigt sich”. O indizível é o que só pode ser mostrado. 
Wittgenstein, leitor e adepto de Tolstói, admirador de Rilke e de Trakl, pôs à conta da literatura, da poesia, por excludência lógica, o que pode ser mostrado (dito numa forma de linguagem não proposicional): a verdade essencial relativa à ação humana, a verdade do ethos de que a Filosofia não pode falar. Ela pode, ironicamente, como fez no caso de Wittgenstein, falar dessa sua impossibilidade, e, por meio dela, transar com a poesia. Mas, concluímos nós, quando a Filosofia e as Ciências se calam, é sempre a poesia que diz a última palavra.

RESUMO - ESTE artigo focaliza as relações entre Poesia e Filosofia, examinando poetas que tenderam à segunda e filósofos inclinados à primeira.

Palavras-Chave: Poesia, Crítica, Filosofia.

ABSTRACT - THIS essay focuses on the relationship between Poetry and Philosophy, examining poets who tended toward the latter and philosophers inclined toward the former.

KEr-WORDS: Poetry, Criticism, Philosophy.

Benedito Nunes nasceu em Belém, Pará, em 21 de novembro de 1929. É professor emérito da UFPA e escritor. Colaborou em obras coletivas nacionais ( $O$ romantismo, $O$ modernismo, Idéias estéticas no Brasil) e estrangeiras, como The Literary Historiography of Brazil in Latin América Literature III, Cambridge, 1966 e Belém, Cultural Center, Literary Cultures of Latin America, A Comparative History II, Oxford University Press, 2004. Individualmente publicou, entre outros, os seguintes livros: $O$ drama da linguagem (Clarice Lispector), 1989; Introdução à filosofia da arte, 1989; O dorso do tigre, 1969; Passagem para o poético (Filosofia e Poesia em Heidegger), 1986 e Filosofia contemporânea, revista e atualizada, 2004.

Recebido em 17.8.2005 e aceito em 21.8.2005. 